\title{
The Performance of Solar Powered Agriculture Sprayer: Design \& Analyze
}

\author{
B.Sravya Reddy ${ }^{1}$, N.Ankitha ${ }^{2}$, Abhinay Sai Kothakonda ${ }^{3}$ \\ ${ }^{1}$ Asst. Professor, CVR College of Engineering/Mechanical Department, Hyderabad, India \\ Email: beeramsravya@gmail.com \\ ${ }^{2}$ Asst. Professor, CVR College of Engineering/Mechanical Department, Hyderabad, India \\ Email: graceankitha@gmail.com \\ ${ }^{3}$ B. tech Student, CVR College of Engineering/Mechanical Department, Hyderabad, India \\ Email: abhinayk999@gmail.com
}

\begin{abstract}
Now-a-days the concept and technology of employing the non-conventional energy have become very popular for all kinds of developmental activities. One of the major areas, which finds a number of application is in Agriculture Sectors. Solar energy plays an important role in drying agriculture products, for irrigation purpose and for pumping the well water in remote villages with no electricity. This technology on solar energy can be extended for spraying pesticides, fungicides, fertilizers and etc., using Solar Sprayers. In the present work, the performance of the solar powered agriculture sprayer is compared with the conventional fuel powered sprayer by considering the various parameters like unit cost, operating cost, weight and maintenance are compared to judge solar agricultural sprayer is better for using in the fields. The experimentation was to find the efficiency of the solar panel and for three different nozzles. The efficiency of the panel keeps on increasing till the value reaches a maximum value at 12:00 and the nozzle efficiency values of all the 3 nozzles under different conditions are greater than $80 \%$.
\end{abstract}

Index Terms: fertilizer tank, solar panel, battery, motor, sprayer and charger.

\section{INTRODUCTION}

Science and technology always help the mankind to improve life. Innovative human brains use their creative power and blend it with the principles of mathematics and physics to develop an ultimate range of plant protection equipments, showcasing the highest degree of human excellence. The invention of solar powered agriculture sprayer brings revolution in the agriculture/horticulture sector. Solar Operated Agriculture Sprayer is a pump runs on electricity generated by photovoltaic panels or the thermal energy available from collected sunlight.

Especially, the invention of sprayers enables farmers to obtain maximum agricultural output. They are used for garden spraying, weed/pest control, liquid fertilizing and plant leaf polishing. It is available in man-portable units, and self-propelled units to boom mounts of 60-151 feet in length. Based on the concept of high pressure, sprayer provides optimum performance with minimum efforts. There are several types of sprayers available in the market such as manual or self-propelled sprayers, tractor mounted sprayers and aerial sprayers.

\section{LITERATURE SURVEY}

1) The studies include Ian F Mahaney et.al [1] who explained the phenomenon of solar energy and how we can use it for all the purposes.
2)H.P.Garg and Prakash et.al [2] explained the different applications of the solar energy in the field of agriculture and daily life. This study showed that solar energy can be put to use in agriculture industry effectively.

3) G.N Tiwari [3] mainly emphasized on the design, construction, performance and application of PV and $\mathrm{PV} / \mathrm{T}$ from the electricity and thermal standpoint. It showed that the temperature is an important factor in influencing the efficiency of the panel.

4) Langsdorf Alexander Suss [4] has given a detailed picture of the AC and DC motors and their use in the industry.

5)Demis H Hill et.al [5] has studied the effects of pests on crops and how to control the pests.He suggested to use less pesticide and start using organic stuff to kill pests.

6)G.A.Mathews et.al [6] has studied and given different methods of application of pesticides.

7)Pistoia, Gianfranco [7] have studied the different kinds of the batteries according to their size, capacity, voltage, etc. They concluded that lithium ion battery is the best portable battery.

8)Furkan Dinçer, Mehmet Emin Meral et.al [8] have studied the factors affecting the efficiency of the solar panels. They concluded that temperature is an important factor that effects the efficiency of the solar panel.

9)Surawdhaniwar, Sonali; Mr. Ritesh Diwan et.al [9] have suggested the use of MPPT technology for the charging of the battery through the solar panel

\section{EXPERIMENTATION}

\section{A. Working Principle of a Sprayer}

The Solar powered agricultural sprayer works same as the normal sprayer, but the only difference is the power required to run the motor in the sprayer is taken from the solar radiation. The PV module is connected to the charge

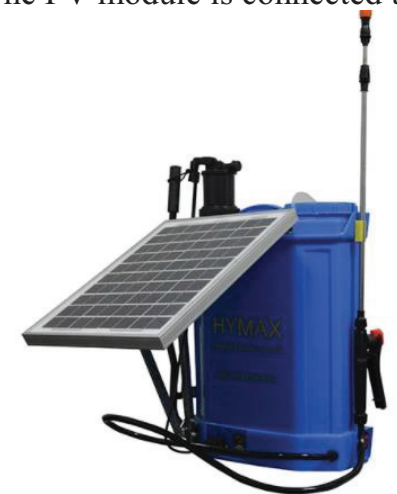

Figure 1. Solar Powered Agriculture Sprayer 
controller, from there the battery to which the charging is to be done is connected to the charge controller, thus the battery can be charged and it is stored. The energy stored in the battery is used in running the motor for spraying the pesticide/fertilizer.

The PV module is kept in sunlight at an angle of 15 degrees preferably so that maximum amount of solar energy can be tracked; the solar energy radiation is then converted into electricity i.e. DC power which is sent directly to the charge controller. The charge controller maintains the amount of electricity passing into the device, so that neither more nor less electricity can be transferred into the devices helping them to work efficiently. From the charge controller the power is transferred to the battery of the sprayer and it is stored in the battery, the charge controller will be useful in maintaining the amount of charge entering into the battery doesn't exceed too much which may defect the battery.

The power saved in the battery taken from solar radiation is used to run the sprayer, the sprayer runs in the same way as it runs if it is charged with electricity from fossil fuel. This type of energy used to run the sprayer is ecofriendly and doesn't cause any pollution to the users. This is the working of the Solar Powered Agricultural Sprayer

\section{B. Types of Agricultural Sprayers}

There are various types of sprayers available in the market. Some of them are:

1. Hand compression Sprayer

2. Power Sprayer

3. Electric Sprayer

4. Backpack/Knapsack Sprayer

5. Motorized mist blower

\section{Technical Specifications of Sprayer}

The following are specifications of solar agriculture sprayer:

$>$ Capacity of fuel tank $=15$ liter

$>$ Pump $=$ Electric Feed Pump 12 volt.

$>$ Material of construction $=$ Plastic Diaphragm.

$>$ Once the battery is recharged fully the sprayer can work up to 4 hours.

$>$ Operating voltage of motor $=12$ volts.

$>$ Battery $=12$-volt, 12 Ah (ampere-hour)

$>$ Discharge $=1500 \mathrm{ml}$. $/ \mathrm{min}$ at 30 PSI $(\max )$

$>$ Weight of solar panel $=1200 \mathrm{gms}$

$>$ Size of panel $=42 \mathrm{~cm} * 84 \mathrm{~cm}$

$>$ Power output from panel $=20$ Watt $(\max )$

$>$ Working Pressure:

Low pressure $=30 \mathrm{psi}$

High Pressure $=40 \mathrm{psi}$

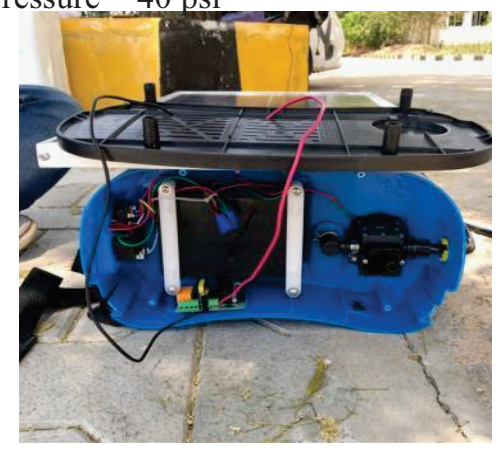

Figure 2. Complete view of the internal assembly
The study was done by comparing the following parameters between a solar powered agricultural sprayer and an I.C engine sprayer.

\section{Unit Cost}

Unit cost of the total product is Rs 4000/- which is a thousand less than a conventional sprayer.

\section{$>$ Operating Cost}

Operating cost is nil as solar power is freely available, whereas in conventional system costs Rs100/- for 1 acre of land.

\section{$>$ Maintenance Cost}

Maintenance cost is also nil as the components used are of good quality which have a life of 5 years whereas in conventional system, it needs continuous maintenance.

\section{$>$ Weight}

Before adding the solar panel and solar charger to the sprayer the weight was $7.1 \mathrm{~kg}$ after adding the weight of the system was $8.2 \mathrm{~kg}$ and after filling it with fertilizer it weighs $11 \mathrm{~kg}$. For a conventional system it weighs around $15 \mathrm{~kg}$.

\section{$>$ Charging Time}

The charging time of the battery is $5 \operatorname{hrs}(9: 00-2: 00)$ the sun's intensity of radiation is high between these timings.

\section{Running Time}

The running time is $4 \mathrm{hrs}$ when the solar panel is disconnected after charging. If it is not disconnected it can keep charging the battery for use.

\section{$>$ Running time with continuous charging}

The running time is $7 \mathrm{hrs}$ when the solar panel is connected with the battery even after charging.

\section{$>$ Efficiency of the solar panel}

The efficiency of the panel is found by measuring the open circuit voltage and short circuit current of the solar panel at intervals of 20mins from 9:00 am to 12:30 pm using multimeter

[9] efficiency of the solar panel $=$ Voc X Isc $/$ PIN

Voc $=$ Open circuit voltage of the panel

Isc $=$ current of solar panel

$\mathrm{PIN}=$ Incident radiation from sun which according to $\mathrm{STC}$ is $1000 \mathrm{~W} / \mathrm{m}^{2}$.

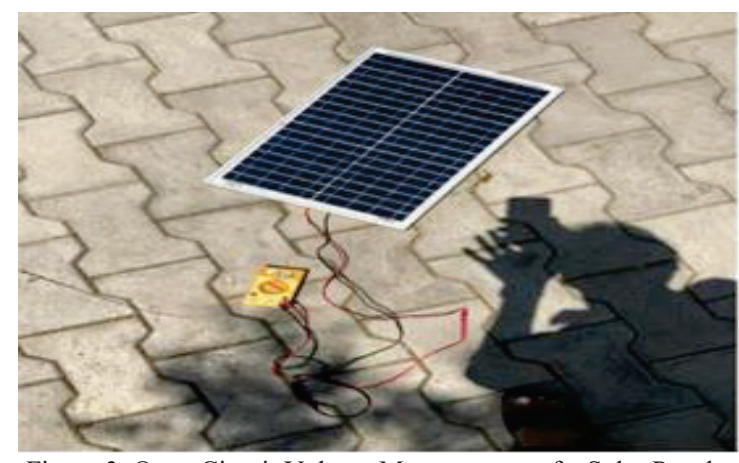

Figure 3. Open Circuit Voltage Measurement of a Solar Panel 
TABLE I.

VOLTAGE, CURRENT AND EFFICIENCY VALUES OF SOLAR PANEL AT DIFFERENT TIME INTERVALS

\begin{tabular}{|c|c|c|c|}
\hline Time & $\begin{array}{c}\text { Voltage(Voc) } \\
(\mathbf{V})\end{array}$ & $\begin{array}{c}\text { Current(Isc) } \\
(\mathbf{A})\end{array}$ & $\begin{array}{c}\text { Efficiency } \\
(\mathbf{\%})\end{array}$ \\
\hline 9 & 19.48 & 1.899 & 10.48 \\
\hline $9: 20$ & 20 & 1.9 & 10.76 \\
\hline $9: 40$ & 20.3 & 1.90 & 10.93 \\
\hline $10: 00$ & 20.6 & 1.91 & 11.15 \\
\hline $10: 20$ & 20.6 & 1.91 & 11.09 \\
\hline $10: 40$ & 20.5 & 1.91 & 11.10 \\
\hline $11: 00$ & 20.7 & 1.91 & 11.2 \\
\hline $11: 20$ & 20.6 & $1 . .89$ & 11.10 \\
\hline $11: 40$ & 20.6 & 1.88 & 11.08 \\
\hline $12: 00$ & 21 & 1.87 & 11.29 \\
\hline $12: 20$ & 21.1 & 1.87 & 11.35 \\
\hline $12: 30$ & 20.7 & 1.86 & 11.10 \\
\hline
\end{tabular}

\section{Flow rate}

The variation of flow rate with respect to time is measured. The values of flow rate at their corresponding times for three different nozzles such as extended range nozzle, standard flat fan nozzle, and even flat fan nozzle are shown in the table and a graph is plotted.

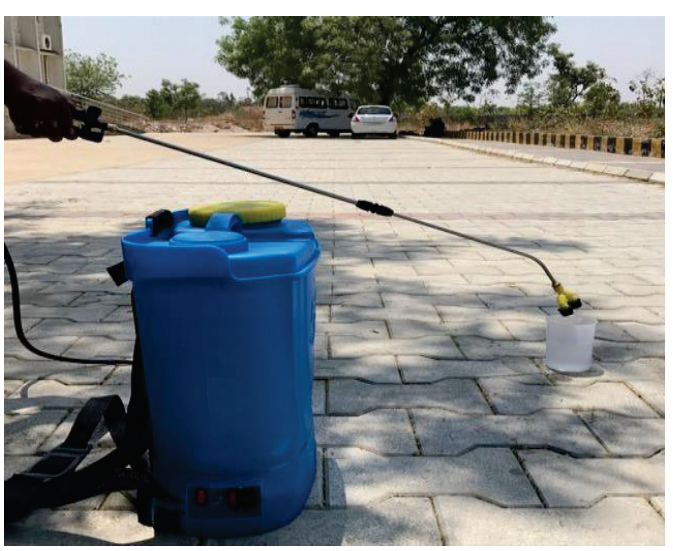

Figure 4. Measuring the flow rate of standard flat fan nozzle using a measuring flask

TABLE II

Flow Rate VALues OF EXTENDEd RANGe NozZLE AT DIFFERENT TIME INTERVALS

\begin{tabular}{|c|c|}
\hline Time(min) & Flow Rate(ml/min) \\
\hline 0 & 2000 \\
\hline 30 & 2000 \\
\hline 60 & 1995 \\
\hline 90 & 1990 \\
\hline 120 & 1880 \\
\hline 150 & 1850 \\
\hline 180 & 1840 \\
\hline 210 & 1820 \\
\hline 240 & 1805 \\
\hline
\end{tabular}

TABLE III.

FLOW RATE VALUES OF STANDARD FLAT FAN NOZZLE AT DIFFERENT TIME INTERVALS

\begin{tabular}{|c|c|}
\hline Time(min) & Flow Rate(ml/min) \\
\hline 0 & 1510 \\
\hline 30 & 1515 \\
\hline 60 & 1499 \\
\hline 90 & 1490 \\
\hline 120 & 1480 \\
\hline 150 & 1450 \\
\hline 180 & 1422 \\
\hline 210 & 1420 \\
\hline 240 & 1410 \\
\hline
\end{tabular}

TABLE IV.

FLOW RATE VALUES OF EVEN FLAT FAN NOZZLE AT DIFFERENT TIME INTERVALS

\begin{tabular}{|c|c|}
\hline \multirow{2}{*}{ Time(min) } & Flow Rate(ml/min) \\
\hline 0 & 1200 \\
\hline 30 & 1200 \\
\hline 60 & 1192 \\
\hline 90 & 1185 \\
\hline 120 & 1170 \\
\hline 150 & 1155 \\
\hline 180 & 1150 \\
\hline 210 & 1125 \\
\hline 240 & 1100 \\
\hline
\end{tabular}

\section{Nozzle Efficiency:}

In this test, we calculate the efficiency of the nozzle by using the actual flow rate in the formula. The values are shown in the table V, VI and VII.

Efficiency $=$ Actual mass flow rate/ Ideal mass flow rate (standard values)

TABLE V.

EFFICIENCY VALUES OF EXTENDED RANGE NOZZLE AT DIFFERENT

\begin{tabular}{|c|c|c|c|}
\hline S.No & $\begin{array}{c}\text { Actual flow } \\
\text { rate(ml/min) }\end{array}$ & $\begin{array}{c}\text { Ideal flow } \\
\text { rate(ml/min) }\end{array}$ & $\begin{array}{c}\text { Efficiency } \\
(\mathbf{\%})\end{array}$ \\
\hline 1 & 2000 & 2100 & 95.23 \\
\hline 2 & 1880 & 2100 & 89.50 \\
\hline 3 & 1805 & 2100 & 85.95 \\
\hline
\end{tabular}

TABLE VI.

EFFICIENCY VALUES OF EVEN FLAT FAN NOZZLE AT DIFFERENT

\begin{tabular}{|c|c|c|c|}
\hline \multicolumn{5}{|c}{ FLOW RATES } \\
\hline S.No & $\begin{array}{c}\text { Actual flow } \\
\text { rate(ml/min) }\end{array}$ & $\begin{array}{c}\text { Ideal flow } \\
\text { rate(ml/min) }\end{array}$ & $\begin{array}{c}\text { Efficiency } \\
(\%)\end{array}$ \\
\hline 1 & 1200 & 1300 & 92.30 \\
\hline 2 & 1170 & 1300 & 90.00 \\
\hline 3 & 1100 & 1300 & 84.6 \\
\hline
\end{tabular}


TABLE VII.

EFFICIENCY VALUES OF STANDARD FLAT FAN NOZZLE AT DIFFERENT FLOW RATES

\begin{tabular}{|c|c|c|c|}
\hline S.No & $\begin{array}{c}\text { Actual flow } \\
\text { rate(ml/min) }\end{array}$ & $\begin{array}{c}\text { Ideal flow } \\
\text { rate(ml/min) }\end{array}$ & $\begin{array}{c}\text { Efficiency } \\
(\mathbf{\%})\end{array}$ \\
\hline 1 & 1510 & 1600 & 94.37 \\
\hline 2 & 1480 & 1600 & 92.75 \\
\hline 3 & 1410 & 1600 & 88.12 \\
\hline
\end{tabular}

\section{RESULTS AND Discussions}

1. A graph is plotted between time and efficiency indicating the efficiency of the panel keeps on increasing till the value reaches a maximum value at 12:00 as shown in the Figure 5.

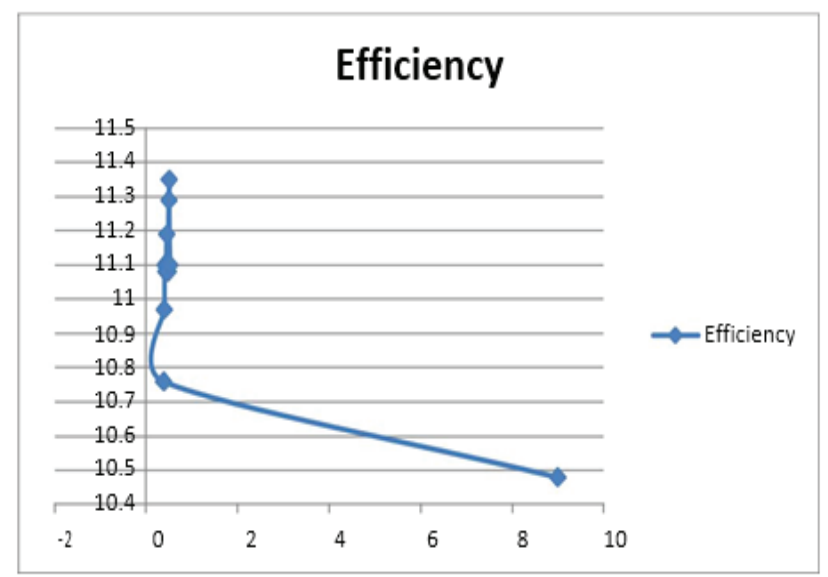

Figure 5. Graph between time and efficiency

2. A graph is plotted between flow rate and time intervals of extended flat nozzle indicate that the flow rate is initially constant and then starts decreasing w.r.t time. The flow rate is the highest in the starting $(2000 \mathrm{ml} / \mathrm{min})$ and the lowest at the end $(1805 \mathrm{ml} / \mathrm{min})$ of the running time as shown in the Figure 6.

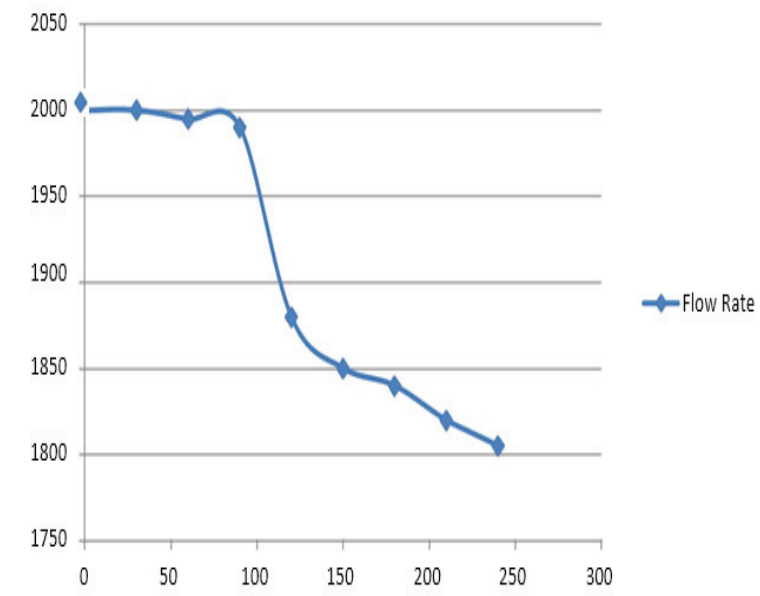

Figure 6. Graph between flow rate and time of extended flat nozzle

3. A graph is plotted between flow rate and time intervals of standard flat fan nozzle indicate that the flow rate is continuously decreasing w.r.t time. The flow rate is the highest in the starting $(1510 \mathrm{ml} / \mathrm{min})$ and the lowest at the end $(1410 \mathrm{ml} / \mathrm{min})$ of the running time as shown in the Figure 7.

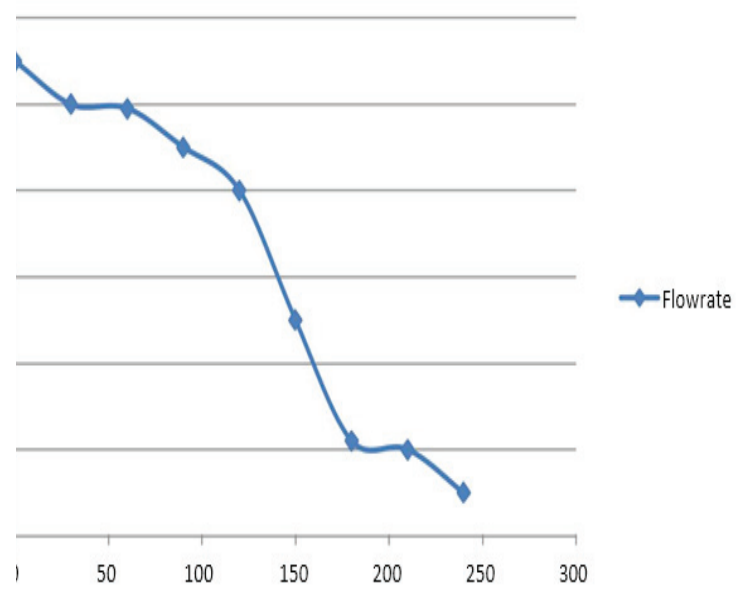

Figure 7. Graph between flow rate and time of Standard flat fan nozzle

4. A graph is plotted between flow rate and time intervals of even flat fan nozzle indicate that the flow rate is continuously decreasing w.r.t time. The flow rate is the highest in the starting $(1200 \mathrm{ml} / \mathrm{min})$ and the lowest at the end $(1100 \mathrm{ml} / \mathrm{min})$ of the running time as shown in the Figure 8 ,

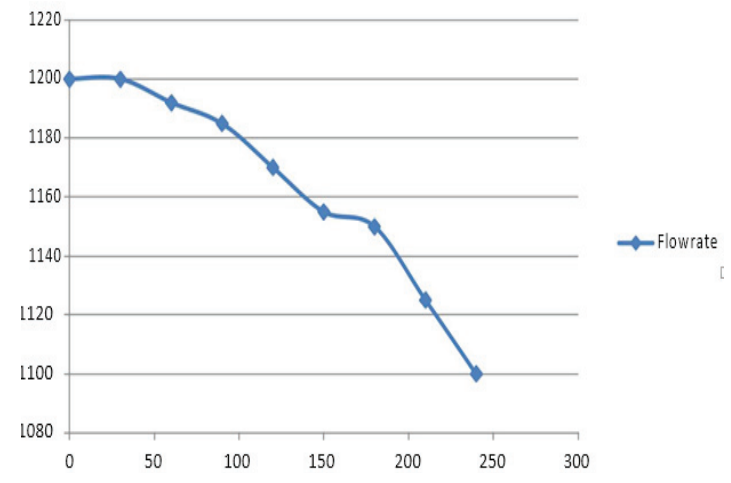

Figure 8. Graph between flow rate and time of even flat fan nozzle

\section{CONCLUSIONS}

The experiments and analysis conducted on the system have given good results while measuring the flow rate, efficiency and nozzle height to range.

1) The V-I characteristics also show that the efficiency of the panel keeps on increasing till the value reaches a maximum value at 12:00.

2) The flow rate of the extended range flat fan nozzle is initially constant and then starts decreasing w.r.t time and the flow rate of the nozzle is $2000 \mathrm{ml} / \mathrm{min}$ which is closer to the ideal value of $2100 \mathrm{ml} / \mathrm{min}$.

3) The flow rate of even flat fan nozzles is continuously decreasing w.r.t time and flow rate of nozzle is around $1200 \mathrm{ml} / \mathrm{min}$ which is closer to the ideal value of $1300 \mathrm{ml} / \mathrm{min}$.

4) The flow rate of Standard flat fan nozzles is continuously decreasing w.r.t time and flow rate of nozzle is around 
$1500 \mathrm{ml} / \mathrm{min}$ which is closer to the ideal value of $1600 \mathrm{ml} / \mathrm{min}$.

5) The nozzle efficiency values of all the three nozzles under different conditions are greater than $80 \%$.

\section{REFERENCES}

[1] Ian F Mahaney, "The Boon of Solar Energy" World Science, Vol. 1, 2002, pp. 1-42.

[2] Garg, Prakash, "Solar Energy Application in Agriculture" Proceedings of the 2006 IEEE 4th World Conference,Vol. 2, May 2006, pp. 2168-2171.

[3] G.N Tiwari, "The Fundamentals of Photo Voltaic Cells and Applications", Published book in june 2005.

[4] Langsdorf, Alexander Suss (1955). Theory of AlternatingCurrent Machinery (2nd ed.). Tata McGraw-Hill. p. 245. ISBN 0-07-099423-4.

[5] Demis .H. Hill, "Agricultural Insect pest Control IEEE, 2006.

[6] G.A.Mathews, "Methods of Applications of Pesticides "Proceedings of the IEEE. 86(8): 1552-1574. CiteSeerX 10.1.1.120. 4059.Pistoia, Gianfranco (2005-01-25), "Batteries for Portable Devices". Elsevier. p. 1. ISBN 0080455565. Retrieved 2016-03-18.

[7] Furkan Dinçer, Mehmet Emin Meral, "A Detailed Picture of Battery", Proceedings of the 2007 IEEE 5th World Conference,Vol. 3, May 2007, pp. 2175-2183.

[8] Surawdhaniwar, Sonali; Mr. Ritesh Diwan (July 2012). "Study of Maximum Power Point Tracking Using Perturb and Observe Method". International Journal of Advanced Research in Computer Engineering \& Technology. 1 (5): 106110. Lipp, Charles W., "Practical Spray Technology: Fundamentals and Practice", 2012, ISBN 978-0-578-10090-6.

[9] http://www.ee.sc.edu/personal/faculty/simin/ELCT566/21\%20 Solar\%20Cells\%20II.pdf

[10] Tom P.Hough, "Analysis of V-I Charateristics", Solid-State and Integrated Circuit Technology, October 1995, pp. 146150 . 